\title{
ОСОБЛИВОСТІ МЕТОДІВ ОБЛІКУ ВИТРАТ І КАЛЬКУЛЮВАННЯ СОБІВАРТОСТІ ПРОДУКЦІї ПІДПРИЄМСТВ ПО ЗАГОТІВЛІ ТА ПЕРЕРОБЦІ ЗЕРНА
}

\section{FEATURES OF COST ACCOUNTING METHODS AND CALCULATION OF PRODUCTION COST PRICE OF ENTERPRISES FOR GRAIN HARVESTING AND PROCESSING}

\author{
Домбровська Наталія Романівна \\ кандидат економічних наук, доцент, \\ Чортківський навчально-науковий інститут підприємництва і бізнесу \\ Західноукраїнського національного університету \\ ORCID: https://orcid.org/0000-0003-1573-7833 \\ Dombrovska Natalia \\ Chortkiv Institute of Entrepreneurship and Business \\ of West Ukrainian National University
}

\begin{abstract}
У статті досліджено методи обліку витрат і калькулювання собівартості продукції, що зумовлено необхідністю поліпшення механізму управління підприємством. Узагальнюючи літературні джерела та практику досліджень підприємств по заготівлі та переробці зерна уточнено економічну сутність категорій «методи обліку витрат» і «методи калькулювання». Розглянуто методи калькулювання собівартості продукції та подано їх характеристику. Обгрунтовано, що використання варіанту ведення виробничого обліку істотно залежить від галузевої специсріки й характеру організації виробництва. 3 цією метою враховуючи галузеву специфіку зернопереробного виробництва, рекомендовано облік витрат здійснювати за однопередільним методом із застосуванням елементів нормативного методу обліку в частині витрачання сировини.
\end{abstract}

Ключові слова: витрати, виробничі витрати, собівартість продукції, калькулювання собівартості, метод, собівартість.

В статье исследованы методы учета затрат и калькулирования себестоимости, что обусловлено необходимостью улучшения механизма управления предприятием. Обобщая литературные источники и практику исследований предприятий по заготовке и переработке зерна уточнено экономическую сущность категорий «методы учета затрат» и «методы калькулирования». Рассмотрены методы калькулирования себестоимости продукции и представлены их характеристику. Обосновано, что использование варианта ведения производственного учета существенно зависит от отраслевой специсики и характера организации производства. С этой целью учитывая отраслевую специфику зерноперерабатывающего производства, рекомендуется учет расходов осуществлять однопередельным методом с применением элементов нормативного метода учета в части расходования сырья.

Ключевые слова: расходы, производственные затраты, себестоимость продукции, калькуляция себестоимости, метод, себестоимость.

The article studies the methods of cost accounting and calculation of production cost price, due to the need to improve the management mechanism of the enterprise. By having summarized the literature sources and the practice of research of enterprises on grain harvesting and processing, the economic essence of the categories "cost accounting methods" and "calculation methods" is specified. The method of production costs accounting is defined as a set of techniques and methods of recording and systematizing information about production costs for current control and management efficiency. In contrast, the method of calculation is considered as a set of techniques and methods of systematization of accounting information about the cost of production and calculation of its cost price to manage the production and marketing activities of the entity. It is substantiated that the use of the variant of production accounting significantly depends on the industry specifics and the nature of the organization of production. For this purpose, taking into account the industry specifics of grain processing, cost accounting is recommended to be 
carried out by a single process stage method using elements of the normative method of accounting in terms of raw materials consumption, which will help to systematically identify deviations of actual costs from current standards. The author emphasizes the need and expediency of the organization of systematic detection of actual costs deviations from current standards, as well as the detection of changes in these standards. In order for the accounting of deviations from the norms to become an effective means of cost management, each component of the system must be carefully designed to the specific conditions of the enterprise. From this position the classifier of deviations from norms is recommended. In order to generalize the causes of deviations in the consumption of raw materials from the norms, having indicated the need, it is proposed a sectoral codifier of the causes of these deviations. According to it, each grain processing enterprise will be able to establish a list in relation to its specifics, assigning the appropriate code to each reason. The use of the considered elements of the normative method of accounting is the basis for proper control and analysis of raw material costs, reasonable calculation of the actual production cost price, control over compliance and improvement of standards.

Keywords: costs, production costs, production cost price, cost price calculation, method, cost price.

Постановка проблеми. В умовах пандемії, як ніколи, суб'єкти господарювання зацікавлені у поліпшенні ефрективності господарської діяльності. Реалізація такого вагомого завдання потребує удосконалення механізму управління суб'єктом господарювання. Ухвалення найкращого управлінського рішення буде відбуватися при умові створення та імплементації в практику управління механізму інформаційної системи, яка у свою чергу зможе впливати на управління діловою активністю підприємства. Підгрунтям механізму такої системи $є$ раціональна організація та продуктивна методика управлінського обліку витрат і калькулювання собівартості продукції.

Аналіз останніх досліджень і публікацій. Проблеми побудови управлінського обліку витрат і калькулювання собівартості продукції $€$ досить популярні серед науковців як зарубіжних так і вітчизняних, таких як: Білоусова І., Дерій В., Корольова О., Онищенко О., Куренна О., Крикуненко А., Палій В., Чумаченко Н. та ін. У той же час багато питань потребують подальшої розробки теоретичних і методологічних аспектів у зв'язку з стрімким розвитком постіндустріальної економіки, що вносить зміни в організацію облікової системи суб'єкта господарювання.

Виділення невирішених раніше частин загальної проблеми. Застосування ефективної та продуктивної методики управлінського обліку витрат і калькулювання собівартості продукції комбінатів хлібопродуктів на часі $€$ найактуальнішим питанням, оскільки від наявності у таких підприємств чіткої політики, яка веде до модифрікації системи витрат для поліпшення її ефрективності, залежить їх конкурентоспроможність на ринку зернопродукції, платоспроможність та кінцевий результат діяльності, що зводиться до отримання якомога більшого прибутку.
Метою статті $€$ визначення оптимальних методів калькулювання та обліку витрат зернопереробних комбінатів для ефективного їх застосування у практичній роботі для зниження та оптимізації витрат на виготовлення зернопереробної продукції.

Викладення основного матеріалу дослідження. Більшість наукової когорти як вітчизняної так і зарубіжної, калькулювання собівартості продукції та методи обліку витрат заносять до основних елементів архітектоніки управлінського обліку. Тому саме в цьому керунку проведено багато досліджень 3 питання обгрунтування методів управлінського обліку. Кожен автор індивідуально підходить до вирішення цієї проблеми.

Поняття методу обліку витрат на виробництво досить неоднозначно трактується в економічній літературі. При цьому авторинауковці по різному розуміють квінтесенцію методу, зокрема, як:

- «економічні прийоми визначення собівартості окремих видів продукції (об'єктів калькулювання)» [1, с. 272];

- «метод обліку витрат повинен характеризувати з необхідною повнотою та деталізацією процес їх виникнення і порядок формування в конкретному виробничому процесі» [2, с. 164];

- «сукупність способів відображення, групування і систематизації даних про витрати, що забезпечують досягнення певної мети. 3 цього погляду методи калькулювання розглядаються як спеціальні методи обліку витрат, що використовуються для розрахунку собівартості певних видів, груп продукції (робіт, послуг)» [3, с. 15];

- «єдиний процес дослідження витрат підприємств певних типів на виробництво та реалізацію продукції з позицій вимірювання, контролю, визначення собівартості виробів і робіт» $[4$, с. 25$]$; 
- «сукупність прийомів організації документування та відображення виробничих витрат, що забезпечують визначення фрактичної собівартості продукції і необхідну інфрормацію для контролю за процесом фрормування собівартості продукції» [5, с. 37].

Найбільш дискусійним постало питання власне не самого тлумачення методу обліку витрат, а його взаємний зв'язок з прийнятими методами калькулювання. На тверде переконання ряду економістів вказані поняття $€$ тотожними, науковці рахують їх нерозривними та пропонують розглядати їх в комплексі [4; 5], інші автори підкреслюють їх нерівнозначність [2; 1].

Ми погоджуємося та схильні з твердженнями та переконаннями тих авторів, які стверджують, що метод калькулювання собівартості продукції та метод обліку витрат на виробництво однозначно $є$ рівноцінно різними поняттями. Метод обліку витрат на виробництво можна означити як сукупність способів та прийомів систематизації і фріксації інфрормаційних відомостей про витрати виробництва для здійснення поточного контролю і есрективності управління ними. На противагу нього, метод калькулювання можна означити як сукупність способів та прийомів систематизації інорормації облікового процесу про витрати виробництва продукції і обчислення її собівартості з метою управління як виробничою так і маркетинговою діяльністю підприємства. Калькулювання $є$ відносно самостійним процесом у системі виробничого обліку, і в той же час інфрормаційні дані калькуляційного обліку та калькуляцій повинні забезпечувати інфрормацією для ухвалення управлінських рішень.

Впродовж всього минулого століття надавалася перевага поділу усіх методів калькулювання за двома окремими керунками. До першої групи відносили позамовний метод обліку витрат. Стосовно другої групи, тлумачення $є$ досить різноманітні - масовий, періодичний, попроцесний, погодинний, передільний. Узагальнюючи їх, можна констатувати, що мова йде про калькулювання масової продукції. У визначенні квінтесенції методу варіюють дві основних ознаки: час (період) і процес. Для створення наукової класифрікації варто розібратися в їхній розбіжності і знайти критерій, що чітко виокремлює методи калькулювання на дві підмножини.

Зазначимо, що Методичними рекомендаціями 3 формування собівартості продукції (робіт, послуг) у промисловості, означено два методи калькулювання: позамовний та попередільний [6]. Згідно з вказаним документом, метод, при якому об'єктом калькулювання і обліку є окреме індивідуальне замовлення, окремий контракт (проект) або партія, що складається 3 продукції ідентичних зразків, які проходять однаковий технологічний процес виготовлення, тлумачиться як позамовний[6]. Зауважимо, що позамовний метод обліку калькулювання трактується однаково майже у всіх літературних надбаннях і співпадає з законодавчою базою.

На сьогоднішній день методичними рекомендаціями визначено застосовування елементів нормативного обліку, як систематичне виявлення відхилень фрактичних витрат від діючих норм, а також виявлення зміни цих норм [6]. Облікова закордонна практика ілюструє, що нормативний метод обліку витрат не береться за основу, через використання його у широкому спектрі організацій та умов у сполученні 3 іншими методами виробничого обліку, позамовним чи будь-яким іншим [7, c. 154].

Моніторинг побудови обліку витрат у наукових напрацювань вчених-економістів дає підстави виокремити два основних підходи. Перший підхід скерований на поліпшення методики обліку витрат і калькулювання собівартості та здійснення контролю витрат за кожним окремим видом господарської діяльності. Йому притаманне виокремлення усіх витрат на непрямі (загальні) та прямі. Системи обліку, які реалізують вказаний підхід, призначені для обчислення витрат повних. Другий підхід скерований на удосконалення методики ухвалення управлінських рішень, навиків їх коригувати залежно від пертурбацій ринкової кон'юнктури зовнішніх чинників. Иого реалізують системи витрат неповних.

До собівартості продукції включаються абсолютно усі витрат, які виникли у ході її виготовлення - це метод повних витрат. Метод неповних витрат на відміну від повного залічує до собівартості продукції лише частку витрат (визначається потребами управління та контролю).

Витрати на виготовлення продукції у згаданих системах групуються у трьох керунках:

- за елементами витрат;

- за центрами відповідальності і центрами виникнення витрат;

- за видами продукції, яка виготовляється.

Перший керунок системи обліку витрат повних завбачує всебічне і точне відбиття усіх витрат, що виникли під час процесу виробни- 
чої діяльності за прямими та непрямими ознаками. Наступний варіант означується тим, якими мають бути витрати на виробництво (інший вид господарської діяльності), що відповідають показникам норми. 3 огляду на це, вартість всіх фрактичних витрат облічується у розрізі тих, які відповідають нормі та відхилені від норм. Система обліку повних витрат за методом нормативним заснована на уявленні про те, якими повинні бути виробничі витрати. Для першого варіанта цієї системи характерним був чіткий поділ витрат лише на прямі та непрямі; поділ витрат на сталі та змінні передбачається вже у всіх теперішніх варіантах.

Відхилення витрат фрактичних від нормативних розцінюється як у результаті зміни обсягу ціни, а також перевитрат чи економії сировини. Облікова система нормативних витрат першочергово раціональна для технологічного контролю. У сьогоднішніх варіантах для фріксації прямих витрат застосовують нормативи (стандарти), а для фріксації непрямих кошториси (бюджети). Тому система тлумачиться як стандарт-кост. У нинішніх варіантах систем обліку нормативних витрат загальні (непрямі) витрати вже чітко поділяються на сталу і змінну частини.

Головним чином система стандарт-кост розглядається як один із важливих інструментів контролю витрат. У американській літературі сутність та визначення системи стандарткост базується на стандартній собівартості: «У системі стандарт-кост всі витрати обчислюються до початку виробництва. Операції, вироби і процеси калькулюються із застосовуванням стандартів у виразі кількісному та грошовому. Розробляються спеціальні рахунки для відбиття фрактичних витрат. Різниця між фактичною та стандартною собівартістю збирається на окремих рахунках» [9, с. 5].

Дозволимо висловити твердження, що система стандарт-кост вважає за можливе розробку норм-стандартів, формування стандартної калькуляції та облік фрактичних витрат із зазначенням відхилень від стандартів.

Зіставлення особливостей системи «стандарт-кост» та нормативного методу обліку витрат дає змогу прослідкувати певні схожості щодо підходів до здійснення контролю витрат виробництва. Однак моніторинг особливостей системи «стандарт-кост» і вивчення нормативного обліку виробництва показує, що це самостійні системи, які у значній мірі відрізняються одна від одної. Відмінності слід розглядати у двох керунках: за змістом, за цілями і задачами системи та за технічними способами і методами [9, с. 6].

Система «стандарт-кост» не $є$ відокремленою чи самостійною. ІІї властивості доводять про можливості застосування як у позаказному, так і процесуальному методах калькулювання собівартості, або в інших певних комбінаціях. Різновидом механізму систем обліку витрат є система «директ-кост», яка надає дані про неповну виробничу собівартість і маржинальний дохід.

У закордонній обліковій практиці велика увага приділяється позиціонуванню принципу точності калькуляції. Це означає, що до собівартості включаються ті витрати, які пов'язані безпосередньо з випуском конкретної продукції. Також методика обрахунку собівартості витрат має бути такою, при якій одержання необхідних інформаційних даних проходило досить оперативно, що дало б змогу використати їх одразу під час здійснення організації виробничого процесу, а не по завершенні звітного періоду (це є характерним для вітчизняного обліку), коли ситуація виправленню не підлягає.

Отже, основним критерієм якості інфрормації у сучасний період повинна виступати оперативність. Калькулювання собівартості зернопродукції та методи обліку витрат на виробництво борошномельної продукції мають бути простими у їх використанні на практиці, вирізнятися гнучкістю та давати можливість спеціалістам в оперативному порядку одержати потрібні інорормаційні дані. При цьому оперативність інорормаційних відомостей превалює над точністю. Оперативність та точність - поняття, які виключають одне одного і знаходяться у зворотньопропорційній залежності. Тобто, менеджер сам повинен вирішувати, яка йому треба інорормація: менш точна та оперативніша чи отримана значно пізніше встановленого терміну та більш точна.

Зауважимо, що сьогодні будь яке вітчизняне підприємство має можливість самостійно визначитись із варіантом побудови бухгалтерського облікового процесу витрат. Для конкретного впровадження на практиці певного методу на суб'єкті господарювання розробляється певний проект роботи. Незалежно від варіанту побудови виробничого обліку має бути забезпечена повна ув'язка інорормаційних відомостей фрінансового обліку з обліком виробничим враховуючи вартісні параметри. При визначенні варіанту обліку витрат береться до уваги характеристика тех- 
нологій, які застосовуються на виробництві, об'єкти калькуляції та організація виробничої діяльності.

На досліджених об'єктах комбінатах хлібопродуктів, враховуючи особливості галузі, облік витрат доцільно проводити за однопередільним (як різновиду попередільного) методом із використанням деталей нормативного методу обліку, що стосується витрачання зерна (сировини).

Автор Мандрика О.В. трактує квінтесенцію «попередільного методу обліку витрат» як облік витрат, що здійснюється за стадіями (фразами) виробничого процесу. Попередільний метод використовується в тому випадку, якщо сировина і матеріали проходять декілька закінчених стадій обробки, і після закінчення кожної стадії виходить не продукт, а напівфрабрикат [11, с. 46]. Науковець В.А. Дерій, відстоює думку, що попередільний (попроцесний) метод обліку витрат на виробництві пов'язаний насамперед із центрами відповідальності, місцями виникнення витрат та статтями калькуляції [12, с. 419].

Дослідники Онищенко О.В., Крикуненко А.С., Куренна О.О. стверджують, що квінтесенція «попередільного методу» полягає у тому, що облік витрат ведеться по переділах, навіть якщо в одному переділі отримують продукцію різних видів. У зв'язку з тим, що напівфрабрикати, отримані в одному переділі, служать вихідним матеріалом у наступному переділі, виникає необхідність їх вартісній оцінці для включення у собівартість продукції наступного переділу [13].

Практика досліджень показує, що однопередільний метод у сполученні з нормативним має досить широку сореру застосування у промисловості. Підприємства, що виготовляють протягом багатьох років однорідну продукцію, як правило, мають технічно обґрунтовані норми матеріальних і трудових витрат та витрат на організацію виробництва і процесу управління. Завдяки цьому і порівняно нечастій зміні технології і організації виробництва встановлені норми протягом року змінюються порівняно рідко і у незначних розмірах.

Коли комбінати хлібопродуктів застосовують попередільний метод обліку витрат, то при цьому необхідно до уваги взяти переділи (види виробництва) та статті витрат. За об'єкти обліку прийнято:

- на борошномельних підприємствах помели;

- на круп'яних - різновиди переробки зернопродукції;
- на підприємствах комбікормових рецепти комбікормів, преміксів, білково-вітамінних добавок, кормосумішей;

- у допоміжних цехах таких виробництв їх переділи.

При практикуванні застосування передільного методу із елементами нормативного методу обліку щодо витрачання сировини доцільно проводити систематичне виявлення відхилень поточних норм від фрактичних витрат, а також виявлення та аналіз змін цих норм. У первинних носіях інорормації та оперативній звітності має відбиватися не лише витрачання сировини фрактичне, але й витрачання ії̈ за нормами.

Облік відхилень від норм на сьогодні $€$ одним із вагомих елементів нормативного методу обліку витрат. Однак для того, щоб він набув статусу дієвого засобу управління собівартістю на підприємстві, потрібно щоб кожний елемент механізму системи був ретельно продуманий згідно визначених умов господарювання. У цій системі важливе місце належить чіткому розумінню класифрікаційних ознак відхилень від норм (рис. 1).

Моніторинг методу обліку витрат, який застосовується на зернопереробних комбінатах, засвідчує фракти несистематичного та неналежного виявлення відхилень витрат фрактичних від нормативних. Інвентарний метод $€$ основним інструментом для виявлення та обліку відхилень від норм витрат сировини. Однак, практика діяльності комбінатів хлібопродуктів дає змогу виділити певні недоліки зазначеного методу:

- акт зачистки складається один раз на місяць, тому фрактичні витрати сировини, а також відхилення від норм виявляються лише у кінці місяця;

- фрорма акту зачистки не прогнозує налагодженого алгоритму виявлення конкретних причин та осіб, які винні у відхиленнях від норм;

- інсрормаційні відомості, що отримуються не відповідають вимогам оперативного управління зернопереробним комбінатом i проведенню контролю за витратами сировини у центрами відповідальності та конкретних місцях виникнення витрат.

Для типізування причин відхилень витрачання матеріалів і сировини від значень норм постає потреба у галузевому кодифрікаторі таких причин. Це дасть змогу кожному борошномельному комбінату встановлювати список та кодифрікувати встановлені причини (табл. 1). Для більш достовірних інфрорма- 


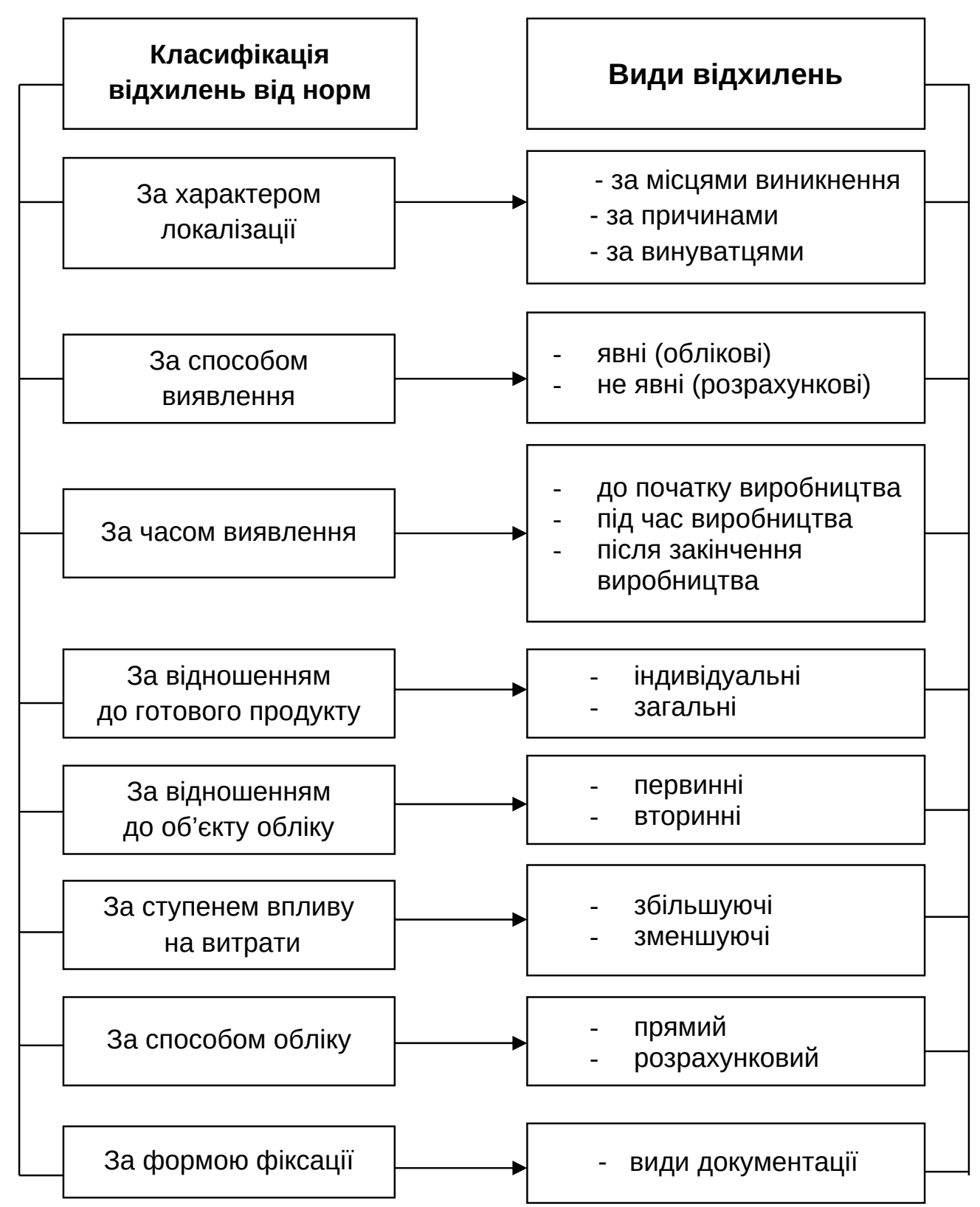

Рис. 1. Класифікація відхилень від норм по матеріальних витратах за окремими ознаками

Джерело: складено автором на основі [10; 11; 12]

ційних даних про причини та осіб, які винні у відхиленнях, такі класифрікатори при потребі можна розширити реквізитами - час виникнення відхилень та місце виникнення.

Використання на практиці елементів нормативного методу обліку має гарантувати своєчасне знаходження додаткових витрат або економії за рахунок відступів від змін складу витраченої сировини або наперед встановленого технологічного процесу.

Отже, застосування у вітчизняній практиці розглянутих елементів нормативного методу обліку слугує здійсненню належного контролю й аналітичної оцінки проведених витрат на сировину і матеріали, аргументованого калькулювання срактичної собівартості продукції, чіткого контролю за додержанням норм. Практика досліджень калькулювання собівартості зернопродукції і використання методів обліку витрат доводить доцільність застосування на зернопереробних комбінатах однопередільного методу обліку витрат 3 використанням елементів нормативного методу обліку щодо витрачання сировини і матеріалів, що позиціонує систематичне виявлення відхилень витрат фрактичних від зазначених норм. 
Таблиця 1

Класифікація причин та винуватців відхилень від норм по сировині та матеріалах у борошномельному цеху

\begin{tabular}{|c|c|}
\hline Причини відхилень & Код \\
\hline $\begin{array}{l}\text { 1. Заміна сировини і матеріалів } \\
\text { 2. Неправильне складання помельних партій зерна } \\
\text { 3. Незадовільна підготовка зерна до помелу } \\
\text { 4. Порушення режимів роботи подрібнювальних машин } \\
\text { 5. Недосіви продуктів } \\
\text { 6. Недобір борошна } \\
\text { 7. Виробіток борошна, не стандартного за крупністю } \\
\text { 8. Виробіток борошна, не стандартного за зольністю } \\
\text { 9. Виробіток борошна, не стандартного за клейковиною } \\
\text { 10. Виробіток борошна з підвищеною вологістю } \\
\text { 11. Погіршання кольору борошна } \\
\text { 12. Поява хрусту в борошні } \\
\text { 13. Незадовільне вимелювання оболонок } \\
\text { 14. Надмірна кількість металомагнітних домішок у борошні } \\
\text { 15. Надмірна усушка } \\
\text { 16. Інші причини }\end{array}$ & $\begin{array}{l}01 \\
02 \\
03 \\
04 \\
05 \\
06 \\
07 \\
08 \\
09 \\
10 \\
11 \\
12 \\
13 \\
14 \\
15 \\
16\end{array}$ \\
\hline Винуватці відхилень & Код \\
\hline $\begin{array}{l}\text { 1. Начальник зміни (бригади) } \\
\text { 2. Лаборант ВТЛ борошномельного цеху } \\
\text { 3. Обійник (зерноочищувальне відділення) } \\
\text { 4. Вальцьові (відповідальні за роботу станків) } \\
\text { 5. Розсівачі (відповідальні за розсіви) } \\
\text { 6. Ситовійник } \\
\text { 7. Технолог } \\
\text { 8. Наладчик } \\
\text { 9. Оператор } \\
\text { 10. Вибійник готової продукції } \\
\text { 11. Начальник цеху готової продукції } \\
\text { 12. Інші робітники борошномельного цеху }\end{array}$ & $\begin{array}{l}001 \\
002 \\
003 \\
004 \\
005 \\
006 \\
007 \\
008 \\
009 \\
010 \\
011 \\
012\end{array}$ \\
\hline
\end{tabular}

Джерело: розроблено автором

\section{СПИСОК ВИКОРИСТАНИХ ДЖЕРЕЛ:}

1. Селезнев С.И., Тарбеев А.А. Курс бухгалтерского учета в промышленности. Москва : Статистика, 1969. 272 c.

2. Палій В.Ф., Соколов Я.В. Теорія бухгалтерського обліку. Москва : Фінанси і статистика, 2004. 279 с.

3. Корольова О.І. Концепція розвитку бухгалтерського обліку витрат в Україні. Економіка. Фінанси. Право. 2008. № 7. С. 13-17.

4. Калькуляция себестоимости в промышленности. Под ред. проф. А.Ш. Маргулиса. Москва : «Финансы», 1975. 295 c.

5. Безруких П.С. Облік та калькулювання собівартості продукції. Москва : Фінанси, 2005. 320 с.

6. Методичні рекомендації з формування собівартості продукції (робіт, послуг) у промисловості (наказ Міністерства промислової політики України № 373 від 09.07.2007р.). URL: http://zakon2.rada.gov.ua.

7. Хорнгрен Ч.Т., Фостер Дж. Бухгалтерский учет: управленческий аспект: Пер. с англ./ Под ред. Я.В. Соколова. Москва : Финансы и статистика, 1995. 416 с.

8. Чумаченко М., Білоусова І. Дискусійні проблеми обліку витрат і калькулювання собівартості продукції. Бухгалтерський облік і аудит. 2008. № 10. С. 3-7.

9. Чумаченко М.Г. Управлінський облік потребує підтримки. Бухгалтерський облік і аудит. 2010. № 5. С. 3-7.

10. Управлінський облік в інсормаційній системі підприємства : навч. посіб. / І.Б. Чернікова та ін. Харківський державний університет харчування та торгівлі. Харків : Видавець Іванченко І. С., 2016. 209 с.

11. Мандрика О.В. Методи обліку витрат та калькуляції собівартості продукції. Культура народов Причерноморья. 2009. № 154. С. 45-47.

12. Дерій В.А. Вітчизняні методи обліку витрат на виробництво: оцінка стану і потенціал застосування. Тернопільський національний університет. Економічні науки. Серія «Облік і фрінанси». 2010. Випуск 7(25). 4. 1. № 7 (1). C. 415-424. 
13. Онищенко О.В., Куренна О.О. Крикуненко А.С. Методи обліку витрат та калькулювання собівартості продукції: вітчизняний та зарубіжний досвід. URL: http://nbuv.gov.ua/UJRN/Nvmgu_eim_2017_25\%282\%29_34.

\section{REFERENCES:}

1. Seleznev S.Y., Tarbeyev A.A. (1969) Kurs bukhhalters'kohoucheta v promishlennosty [Industrial Accounting Course]. Moskow. (in Russian)

2. Palij V.F., Sokolov Ya.V. (2004) Teoriia bukhhalters'koho obliku [Accounting theory]. Moskow: Finances and Statistics. (in Russian)

3. Korol'ova O.I. (2008) Kontseptsiya rozvytku bukhhalters'koho obliku vytrat v Ukrayini [The concept of development of cost accounting in Ukraine]. Ekonomika. Finansy. Pravo, vol. 7, pp. 13-17.

4. Margulis A.Sh. (1975) Kal'kulyatsiya sebestoimosti v promyshlennosti [Industrial costing]. Moskow: Finansy. (in Russian)

5. Bezrukikh P.S. (2005) Oblik ta kaljkuljuvannja sobivartosti produkciji [Accounting and costing of products] Moskow: Finances. (in Russian)

6. Nakaz Ministerstva promyslovoi polityky Ukrainy (09.07.2007) № 373. Metodychni recomendatsii z formuvannia sobivartosti produktsii (robit, posluh) u promyslovosti [Methodical recommendations on formation of products cost (works, services) in industry]. Available at: http://zakon2.rada.gov.ual

7. Khorngren CH.T., Foster Dzh. (1995) Bukhgalterskiy uchet: upravlencheskiy aspekt [Accounting: management aspect] Moskow: Finances and Statistics. (in Russian)

8. Chumachenko M., Bilousova I. (2008) Dyskusijni problemy obliku vytrat i kaljkuljuvannja sobivartosti produkciji [Discussion problems of cost accounting and product costing]. Bukhghaltersjkyj oblik $i$ audyt, vol. 10, pp. 3-7. (in Ukrainian)

9. Chumachenko N.Gh. (2010) Upravlinsjkyj oblik potrebuje pidtrymky. [Management accounting needs support]. Bukhghaltersjkyj oblik i audyt, vol. 5, pp. 3-7. (in Ukrainian)

10. Chernikova I.B. (2016) Upravlinsjkyj oblik v informacijnij systemi pidpryjemstva. Navchaljnyj posibnyk [Management accounting in the enterprise information system]. Kharkiv: Vydavecj Ivanchenko I.S. (in Ukrainian)

11. Mandryka O.V. (2009) Metody obliku vytrat ta kaljkuljaciji sobivartosti produkciji [Methods of cost accounting and costing of products]. Kuljtura narodov Prychernomorjja, vol. 145, pp. 45-47. (in Ukrainian)

12. Derij V.A. (2010) Vitchyznjani metody obliku vytrat na vyrobnyctvo: ocinka stanu i potencial zastosuvannja. [Domestic methods of accounting for production costs: assessment of the state and potential application]. Ternopiljskyj nacionaljnyj universytet. Ekonomichni nauky. Seriia «Oblik i finansy», vol. 7(25), pp. 415-424. (in Ukrainian)

13. Onyshhenko O.V., Kurenna O.O. Krykunenko A.S. (2021) Metody obliku vytrat ta kaljkuljuvannja sobivartosti produkciji: vitchyznjanyj ta zarubizhnyj dosvid. [Methods of cost accounting and product costing: domestic and foreign experience]. Available at: http://nbuv.gov.ua/UJRN/Nvmgu_eim_2017_25\%282\%29_34. (in Ukrainian) 